\title{
Clinical and Demographic Profile of Acute Anterior Uveitis: A Hospital Based Study
}

\author{
Anu Gurung', Dhan Bahadur Shrestha', Pravash Budhathoki³, Sachit Dhakal', Sagar \\ Rajkarnikar $^{1}$, Kamala Thapa ${ }^{1}$ and Ram Shrestha ${ }^{1}$
}

${ }^{1}$ Department of Ophthalmology, Nepalese Army Institute of Health Sciences, Shree Birendra Hospital, Chhauni, Kathmandu, Nepal

${ }^{2}$ Mangalbare Hospital, Urlabari-3, Morang, Nepal

${ }^{3}$ Dr Iwamura Hospital, Bhaktapur, Nepal

\begin{abstract}
Introduction: Uveitis is an inflammatory condition of uvea of eye. It is a sight threatening condition, so accurate and timely diagnosis and treatment is required. Acute anterior uveitis is characterised by eye pain or photophobia, circumlimbal redness and anterior chamber cells and flare.

Methods: This is a cross-sectional descriptive hospital record-based study based on data record in eye department of a tertiary care level centre in Kathmandu, Nepal. All cases of anterior uveitis presented to our OPD over one-year duration (December 2017- November 2018) were enrolled. Age, sex, co-morbidities and profile of uveitis like slit lamp findings were recorded.

Results: Total 52 cases of acute uveitis were observed during the study period. There were total 34 males and 18 females with eye involvement. Age group of the patients ranged from 19 to 79 years with median age of 36 years. Forty eight cases $(92.3 \%)$ had unilateral involvement whereas only four cases $(7.7 \%)$ had bilateral involvement. Keratic precipitates were seen in 44 patients. Majority of the patients had good vision; $65.4 \%$ in right eye and $69.2 \%$ in left eye.

Conclusions: Most of the anterior uveitis occur in male in third and fourth decade. The most common complaints of the patient were decreased vision, eye pain and red eye.

Key words: decreased vision; uveitis; Nepal
\end{abstract}

Correspondence: Anu Gurung, Department of Ophthalmology, Nepalese Army Institute of Health Sciences, Shree Birendra Hospital, Chhauni, Kathmandu, Nepal. E-mail: gurung.anu@gmail.com

DOI: http://dx.doi.org/10.3126/mjsbh.v19i2.28285

Submitted on: 2020-03-13

Accepted on: 2020-05-09

This work is licensed under creative common license:

http://creativecommons.org/licenses/by-nc-nd/4.0/ @ MJSBH 2020 


\section{INTRODUCTION}

Uveitis is an inflammatory condition of middle vascular coat of the eye (uvea) and acute anterior uveitis is the commonest type. It causes blindness and visual impairment in a significant number of people in most communities. ${ }^{1}$ Being a sight threatening condition accurate and timely diagnosis of anterior uveitis by proper examination and its appropriate management is of utmost importance. ${ }^{2}$ Anterior uveitis is associated with HLA-B27 allele which is also associated with different immunological and rheumatologic diseases like seronegative arthropathy. ${ }^{3}$ Acute anterior uveitis is characterised by eye pain, photophobia, circumlimbal redness and anterior chamber cells and flare. ${ }^{2}$ Proper physical and systemic examination with added ophthalmological investigations may be needed to rule out other associated systemic or ocular diseases. ${ }^{2,4}$ This study was done with the aim to evaluate the profile of acute anterior uveitis cases presenting to tertiary centre located in Kathmandu, Nepal based on clinical and slit lamp examination findings. It is prime document to explore our experience in the institute and will help in further management perspective of the cases.

\section{METHODS}

This was a non-interventional retrospective crosssectional descriptive study based on data record in Eye Department of our institute. The study period was of one year from December 2017 - November 2018. All cases of anterior uveitis presenting to us for further workup and management were enrolled in the study. Patients who were suspected to have uveitis at presentation but turned out to have different diagnosis on further evaluation were excluded. Age, sex, co-morbidities and profile of uveitis like slit lamp findings were recorded. Anterior chamber cells and flare are visible owing to the Tyndall effect of the bright beam. Cells and flare were observed on slit lamp examination in a field defined as a $1 \times 1 \mathrm{~mm}$ high power beam at full intensity at a 45 - 60 degree angle in a dark room.

Prior to conducting the study ethical clearance was taken from local Institutional Review Committee. Detailed laboratory investigation was advised only for recurrent and bilateral cases. Laboratory investigations carried out were total and differential count, Erythrocyte Sedimentation Rate (ESR), Venereal Disease Research Laboratory (VDRL),
Angiotensin Converting Enzyme (ACE), RA factor, $\mathrm{X}$ ray chest and TORCH infections. Further analysis was done after collection of the data.

\section{RESULTS}

A total of 52 cases of anterior uveitis were observed during the study period. Among the participants, the median age was 36 years with the youngest participant being 19 years and oldest of 79 years. No paediatric cases were seen in our study. There

Table 1. Clinical parameters observed

\begin{tabular}{|c|c|c|c|}
\hline \multicolumn{2}{|l|}{ Variables } & \multirow{2}{*}{$\begin{array}{l}\begin{array}{l}\text { Number of } \\
\text { patients }\end{array} \\
34\end{array}$} & \multirow{2}{*}{$\begin{array}{r}\text { Percent } \\
65.4\end{array}$} \\
\hline Sex & Male & & \\
\hline & Female & 18 & 34.6 \\
\hline \multirow[t]{4}{*}{ Eye } & Right & 26 & 50.0 \\
\hline & Left & 22 & 42.3 \\
\hline & Bilateral & 4 & 7.7 \\
\hline & Unilateral & 48 & 92.3 \\
\hline \multirow[t]{2}{*}{ KPs } & No & 11 & 21.2 \\
\hline & Yes & 41 & 78.8 \\
\hline \multirow[t]{2}{*}{ SPK } & No & 44 & 84.6 \\
\hline & Yes & 8 & 15.4 \\
\hline \multirow[t]{3}{*}{ Flare } & $1+$ & 25 & 48.1 \\
\hline & $2+$ & 8 & 15.4 \\
\hline & $3+$ & 2 & 3.8 \\
\hline \multirow[t]{3}{*}{ AC cells } & $1+$ & 18 & 34.6 \\
\hline & $2+$ & 25 & 48.1 \\
\hline & $3+$ & 9 & 17.3 \\
\hline \multirow[t]{3}{*}{$\begin{array}{l}\text { Visual } \\
\text { acuity (R) }\end{array}$} & $\begin{array}{l}\text { Poor } \\
(<6 / 60)\end{array}$ & 5 & 9.6 \\
\hline & $\begin{array}{l}\text { Borderline } \\
(6 / 24-6 / 60)\end{array}$ & 11 & 21.2 \\
\hline & $\begin{array}{l}\text { Good } \\
(6 / 6-6 / 18)\end{array}$ & 36 & 69.2 \\
\hline \multirow[t]{3}{*}{$\begin{array}{l}\text { Visual } \\
\text { acuity (L) }\end{array}$} & $\begin{array}{l}\text { Poor } \\
(<6 / 60)\end{array}$ & 6 & 11.5 \\
\hline & $\begin{array}{l}\text { Borderline } \\
(6 / 24-6 / 60)\end{array}$ & 12 & 23.1 \\
\hline & $\begin{array}{l}\text { Good } \\
(6 / 6-6 / 18)\end{array}$ & 34 & 65.4 \\
\hline
\end{tabular}


$\begin{array}{llll}10-20 & \bigcirc \\ 50-60 & 20-30 & 30-40 & \bigcirc \\ 60-70 & 40-50 \\ 7-80 & \end{array}$

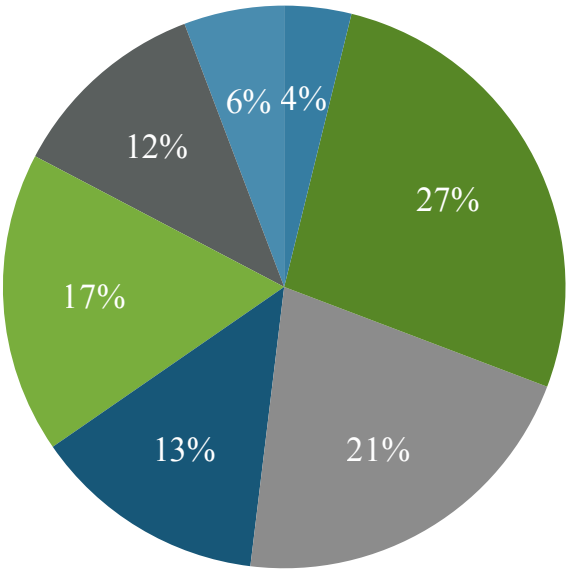

Figure 1. Pie-chart showing age distribution

was a total of 34 males and 18 females with sex ratio of 1.88. Unilateral involvement was seen in 48 cases $(92.3 \%)$ which was more common than bilateral involvement which was seen in only four cases $(7.7 \%)$. There were keratic precipitates in 41 patients $(78.8 \%)$. Poor visual acuity was seen in six patients in left eye and five patients in right eye. Majority of the patients had good vision, $65.4 \%$ in right eye and $69.2 \%$ in left eye. (Table 1 )

There were no paediatric patients in our study. Highest number of cases were seen in age group of $20-30(27 \%)$ years followed by $30-40(21 \%)$ years with the least number in age group of $10-20$ (4\%) years. (Figure 1.) Diminished vision was the commonest presenting complaint (94.2\%) followed

Unclassified Rheumatoid Arthritis

Traumatic

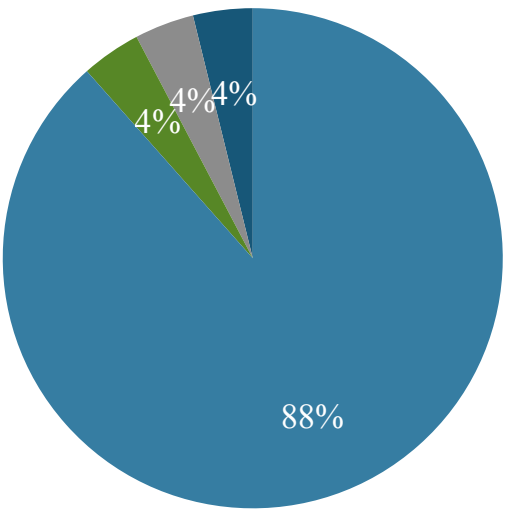

Figure 3. Pie-chart of etiology of uveitis

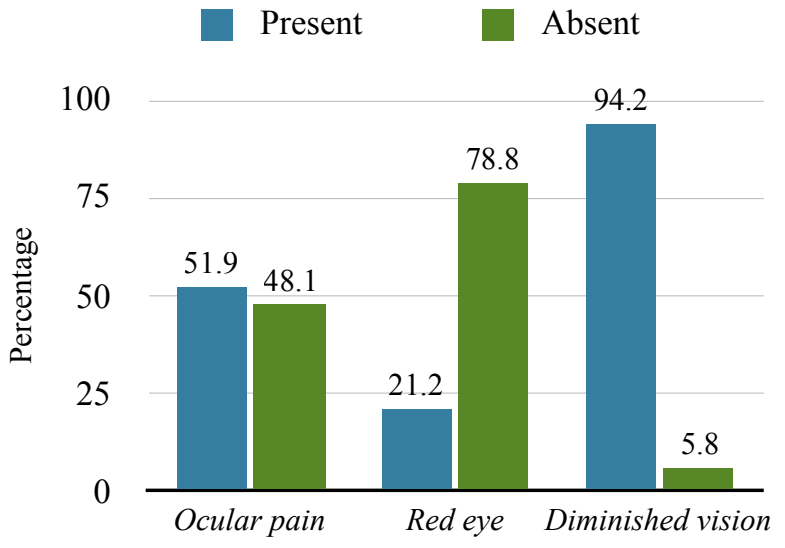

Figure 2. Bar diagram showing presenting complaints

by ocular pain (51.9\%). Red eye $(21.2 \%)$ was the least common symptom in our study. (Figure 2) The specific cause of anterior uveitis were traumatic, infective and rheumatoid arthritis each with $4.0 \%$ while in rest, the cause was not delineated. (Figure 3)

\section{DISCUSSION}

Our study provides clinical profile of uveitis in our institute, which is a tertiary level referral centre of our country. In our study, the median age of uveitis was 36 years with range of 19 to 79 years. It is consistent with similar studies conducted in other parts of the world. ${ }^{5,6}$ Sex ratio of 1.8/1 was found in our study which contrasts with equal findings in both male and female in other study conducted in Nepal in Tilganga hospital ${ }^{7}$ and study conducted in Africa. ${ }^{5}$ Studies done in India showed increased number of cases in males. ${ }^{8,9}$ Maximum number of cases were found in $3^{\text {rd }}$ and $4^{\text {th }}$ decade of life about $26.9 \%$ and $21.1 \%$ respectively, similar to the study conducted in Africa and Iran. 5,10

Predominance of unilateral cases $(92.3 \%)$ was seen in our studies similar to the studies conducted in Nepal and other parts of the world. 5,7 The most common presenting symptoms was decreased vision $(94.2 \%)$ followed by ocular pain (51.9\%) with red eye (21.2\%). The reason behind decreased vision could be due to anterior chamber cells and flare and due to cornea involvement in keratouveitis cases. On the contrary, a study done in Japan showed red eye (51.8\%) as the most common presenting symptom followed by reduced vision $(28.6 \%)$ and ocular pain (17.9\%). ${ }^{11}$ The visual acuity was good $(6 / 6-6 / 18)$ in right eye of $69.2 \%$ patients and left eye of $65 \%$ of patients. As patients complained of decreased vision, this symptom was mentioned rather than blurring of vision. However, 
most of the patients had good vision in spite of complaints of decreased vision. Majority of patients didn't complain of photophobia in our study. About $88 \%$ of cases of anterior uveitis were idiopathic (unclassified) followed by trauma, infective and rheumatoid arthritis each with $3.8 \%$. The definitive etiological diagnosis of our study was about $11.4 \%$ which is less compared to Indian Subcontinent and a study in Srilanka with $35 \% .^{12,13}$ Most studies done around the world and study in Nepal show infectious herpes virus to be the most common cause of anterior uveitis. $5,7,14$ Two cases of herpes associated uveitis were seen in our study with associated keratitis. Our study is a retrospective study with limited number of sample size in a single centre, which is a major limitation of our study.

\section{CONCLUSIONS}

This study served to evaluate the clinical scenario of anterior uveitis in a tertiary level teaching institute of Nepal. Most of the cases occurred in males with the highest incidence seen in third and fourth decade. Majority had unilateral involvement. The most common complaints of the patient were decreased vision, eye pain and red eye. Further multi centric studies are required to extrapolate this data to the entire country.

To cite this article: Gurung A, Shrestha DB, Budhathoki P, Dhakal S, Rajkarnikar S, Thapa K, et al. Clinical and demographic profile of acute anterior uveitis: A hospital based study. MJSBH. 2020;19(2):75-79.

Conflict of Interest: None declared

\section{REFERENCES}

1. Wakefield D, Chang JH. Epidemiology of uveitis. Int Ophthalmol Clin. 2005;45(2):1-13. DOI: https://doi.org/ 10.1097/01.iio.0000155938.83083.94PMid:15791154

2. Agrawal R, Murthy S, Sangwan V, Biswas J. Current approach in diagnosis and management of anterior uveitis. Indian J Ophthalmol. 2010;58(1):11-9. DOI: https://doi.org/10.4103/0301-4738.58468

3. Selmi C. Diagnosis and classification of autoimmune uveitis. Autoimmun Rev. 2014;13(4-5):591-4. DOI: https:// doi.org/10.1016/j.autrev.2014.01.006

4. Guly CM, Forrester JV. Investigation and management of uveitis. BMJ. 2010;341:4976. DOI: https://doi.org/ 10.1136/bmj.c4976

5. Khairallah M, Yahia SB, Ladjimi A, Messaoud R, Zaouali S, Attia S, et al. Pattern of uveitis in a referral centre in Tunisia, North Africa. Eye (Lond). 2007;21(1):33-9. DOI: https://doi.org/10.1038/sj.eye.6702111

6. Rodriguez A, Calonge M, Pedroza-Seres M, Akova YA, Messmer EM, D'Amico DJ, et al. Referral patterns of uveitis in a tertiary eye care center. Arch Ophthalmol. 1996;114(5):593-9. DOI: https://doi.org/10.1001/archopht. 1996.01100130585016

7. Manandhar A. Patterns of Uveitis and Scleritis in Nepal: A Tertiary Referral Center Study. Ocul Immunol Inflamm. 2017;25(1):54-62. DOI: https://doi.org/10.3109/09273948.2016.1161804

8. Das D, Bhattacharjee H, Bhattacharyya PK, Jain L, Panicker MJ, Das K, et al. Pattern of uveitis in North East India: A tertiary eye care center study. Indian J Ophthalmol. 2009;57(2):144-6. DOI: https://doi.org/ 10.4103/0301-4738.45506

9. Rathinam SR, Namperumalsamy P. Global variation and pattern changes in epidemiology of uveitis. Indian J Ophthalmol. 2007;55(3):173-83. DOI: https://doi.org/10.4103/0301-4738.31936

10. Kianersi F, Mohammadi Z, Ghanbari H, Ghoreyshi SM, Karimzadeh H, Soheilian M. Clinical Patterns of Uveitis in an Iranian Tertiary Eye-care Center. Ocul Immunol Inflamm. 2015;23(4):278-82. DOI: https://doi.org/ $10.3109 / 09273948.2014 .902474$

11. Keino H, Watanabe T, Taki W, Nakayama M, Nakamura T, Yan K, et al. Clinical features of uveitis in children and adolescents at a tertiary referral centre in Tokyo. Br J Ophthalmol. 2017;101(4):406-10. DOI: https://doi.org/ 10.1136/bjophthalmol-2015-308194 
12. Siak J, Kumaradas M, Chee SP. The Pattern of Uveitis in Sri Lanka. Ocul Immunol Inflamm. 2017;25(1):63-8. DOI: https://doi.org/10.1080/09273948.2017.1313991

13. Singh R, Gupta V, Gupta A. Pattern of uveitis in a referral eye clinic in north India. Indian J Ophthalmol. 2004;52(2):121-5. PMID: 15283216

14. Miettinen R. Incidence of uveitis in Northern Finland. Acta Ophthalmol (Copenh). 1977;55(2):252-60. DOI: https:// doi.org/10.1111/j.1755-3768.1977.tb01306.x 